\title{
Empirical Investigation of the Role of Emotional Intelligence on Employees' Work Engagement in Banking Industry in South- western Nigeria
}

\section{Solomon Ojo Ph.d}

Department of Human Resource Development, Faculty of Management Sciences, Okuku Campus, Osun State University.

\section{ABSTRACT}

The study investigated the role of Emotional Intelligence on employees' work Engagement in banking industry. A total 804 bank employees took part in the study, in which 364 (45.3\%) were males while $440(54.7 \%)$ were females, with a mean age of 33.38 yrs ( $S D=7.98 y r s)$. Questionnaire format was employed for data collection, which was made into a number of sections and into several copies for data collection. Both the Descriptive and Inferential statistics were adopted for data analysis. Specifically, the Statistical Packages for Social Sciences (SPSS) version 17.0 was utilized for data analysis.

How to cite this article:

The results revealed that bank employees who were high on emotional intelligence reported more work engagement than bank employees who are low on emotional intelligence [t (802) $=3.20, P<.05]$. The result equally showed that bank employees who were found high on some measures of emotional intelligence reported more work engagement than bank employees who were low on some of the measures.

The results were discussed extensively in relation to relevant existing bodies of literature.

\section{Keywords:}

Solomon Ojo. Empirical Investigation of the Role of Emotional Intelligence on Employees' Work Engagement in Banking Industry in South-western Nigeria. International Journal of Industrial and Business Management, 2017; 1:1.

Emotional intelligence, Work engagement, Banking Industry, Bank Employees, South-western Nigeria.

\section{eSciencePublisher} eSciPub LLC, Houston, TX USA. Website: http://escipub.com/ 


\section{INTRODUCTION}

The concepts of emotional intelligence and work engagement have been found to receive significant attention in both academia and the business popular press in recent years. As such, much of the attention has focused on the relationship each concept has with organizational results and leadership performance. Importantly, there have been debates amongst researchers of how best to define and measure emotional intelligence, and whether emotional intelligence is a new type of intelligence or simply another way of assessing personality characteristics (Mayer, Salovey, \& Caruso, 2000 cited in cited in Thor and Johnson, 2013). More importantly, Work engagement, although not as widely researched as emotional intelligence, is said to have little consensus amongst scholars and business consultants in terms of the construct and definition and as much has faced criticism for failure to distinguish itself from similar concepts such as job satisfaction and flow (Schaufeli\& Bakker, 2010 cited in Thor and Johnson, 2013).

However, the origins of engagement academic research began with Kahn (1990 cited in Thor and Johnson, 2013) who studied camp counselors and employees of an architectural firm. Kahn was said to seek an understanding of what conditions led to personal engagement, which he defines as "the harnessing of organization members' selves to their work roles" (p. 694). Since Kahn's research in engagement in the early 1990s, the popularity of the subject has risen significantly with consulting firms taking the lead in publishing a variety of concepts and definitions to describe the phenomenon (Towers Perrin, 2003, 2007; Wagner \& Harter, 2006). Only recently has the academic community begun to more widely study engagement (Schaufeli\& Bakker, 2010 cited in Thor and Johnson, 2013).

The engagement literature has used "employee engagement" and "work engagement" to describe a similar phenomenon. For example, Schaufeli and Bakker (2010) argue that work engagement is a description for the relationship one has with her/his work, whereas employee engagement is the relationship one has with the organization. Bakker, Schaufeli, Leiter, and Taris (2008 cited in Thor and Johnson, 2013) describe the concept of work engagement as "a positive, fulfilling, affective-motivational state of work-related wellbeing that is characterized by vigor, dedication, and absorption" (p. 187). This construct of work engagement has led to the development of the Utrecht Work Engagement Scale (UWES), which is the most widely utilized engagement instrument for academic research (Schaufeli, Salanova, Gonzalez-Roma, \& Bakker, 2002 cited in Thor and Johnson, 2013). Various consulting firms have also developed proprietary instruments for measuring engagement (Towers Perrin, 2003, 2007; Wagner \& Harter, 2006).

Nonetheless, the concept of work engagement has faced criticism in comparison with established concepts such as job involvement (Lodahl \&Kejner, 1965 cited in Thor and Johnson, 2013), job satisfaction (Locke, 1976), flow (Csikszentmihalyi, 1990), and organizational commitment (Mowday, Steers, \& Porter, 1979 cited in Thor and Johnson, 2013). While each of these concepts has similarities to work engagement, Schaufeli and Bakker (2010 cited in Thor and Johnson, 2013) argue work engagement has value that goes above and beyond these concepts by offering a new perspective in understanding individual commitment to work. Research in emotional intelligence and work engagement is beginning to build a case that both concepts are related to improvement in individual, leadership, and organizational performance. Individuals who are emotionally intelligent have been found to receive higher performance reviews, have higher rank within a company, and generally outperform those with lower intelligence (Law, Wong, \& Song, 2004; Lopes, Grewal, Kadis, Gall, \&Saloveyk, 2006; Van Rooy\&Viswesvaran, 2004).

In view of the above analysis, this study as therefore meant to empirically investigate the role of emotional intelligence on work engagement in banking industry in South-Western Nigeria. This study actually investigated the overall impact of emotional intelligence on work engagement in banking industry. The study equally examined the specific role of each of the selected items measuring emotional intelligence on work engagement in banking industry in South-Western Nigeria.

It is hoped to however, that this study will contribute to the existing body of knowledge on the 
relationship between emotional intelligence and work engagement in work organization and particularly in banking industry. The findings of this study shall be useful to management, employers and employees on how to improve work engagement in the workplace through the contributions of emotional intelligence possessed by employees.

\section{LITERATURE REVIEW \\ Theoretical framework}

\section{Models of Emotional Intelligence}

Today, there are three generally accepted conceptual models of Emotional intelligence (EI) namely:

(1) The Salovey-Mayer model, which is primarily cognitive.

(2) The Goleman model, which is directed at emotional domains and competencies.

(3) The Bar-On model which focuses on behavioural traits.

Based on the Mayer and Salovey'sFour branch Framework of Emotional Intelligence, Mayer and Salovey (1997 cited in Permall, 2011) conceptualize $\mathrm{El}$ as a four branch model describing four areas of capacities or skills that collectively describe many areas of emotional intelligence. This model defines emotional intelligence as involving the abilities to:

1. Accurately perceive emotions in oneself and others: This has to do with the non-verbal reception and expression of emotion.

2. The capacity to accurately perceive emotions in the face or voice of others provides a crucial starting point for more advanced understanding of emotions.

3. Use emotions to facilitate thinking: This refers to the capacity of the emotions to enter into and guide the cognitive system and promote thinking.

4. Understand emotional meanings: Understanding emotional messages and the actions associated with them is one important aspect of this area of skill.

5. Manage emotions: Emotions often can be managed, it becomes possible to regulate and manage one's own and others' emotions so as to promote one's own and others' personal and social goals. Mayer (cited in Mayer et al., 2004, p. 197 cited in Permall, 2011) explains that the "order of the branches, from perception to management, represents the degree to which the ability is integrated within the rest of an individuals' major psychological subsystems - that is, within his or her overall personality".

\section{Secondly, according to Goleman's Emotional Competence Inventory}

Goleman (2001, p.27 cited in Permall, 2011) defines El as "a learned capability based on emotional intelligence that results in outstanding performance at work". Boyatzis, Goleman and Rhee (2000) demonstrate a long-standing interest in the workplace and what supports exceptional leadership, management and effectiveness in the work context. These authors base their model of El on those competencies enabling individuals to demonstrate intelligent use of their emotions in effectively managing both themselves and others at work. They view El as a convenient phrase to focus attention on human talent and to anchor the consequences of the individual's behaviour; and more specifically, success or effectiveness at work.

McGarvey (1997 cited in Permall, 2011) maintains that those individuals with the highest emotional intelligence excel at four interrelated skills:

1. The ability to persist and stay motivated in the face of frustration;

2. The ability to control impulses;

3. The ability to control their emotions; and

4. The ability to empathize with others.

McGarvey (1997 cited in Permall, 2011) claims that these factors are now considered to have greater impact on individual and group performance than traditional measures of intelligence such as IQ.

Thirdly, Bar-On's model of emotional social intelligence, influenced by the work of Darwin, Thorndike and Weschsler provide the theoretical basis for the EQ-i. According to this model, emotional-social intelligence is a cross section of 
Solomon Ojo, IJIBM, 2017; 1:1

Table 1: A table showing the socio-demographic characteristics of the participants in the study

\begin{tabular}{|c|c|c|}
\hline Variables & Number & Percentage \\
\hline \multicolumn{3}{|l|}{ Gender : } \\
\hline Male & 364 & 45.3 \\
\hline Female & 440 & 54.7 \\
\hline \multicolumn{3}{|l|}{ Marital Status: } \\
\hline Single/ Never Married & 276 & 34.3 \\
\hline Married & 376 & 46.8 \\
\hline Divorced & 72 & 9.0 \\
\hline Separated & 64 & 8.0 \\
\hline Widower / widow & 16 & 2.0 \\
\hline \multicolumn{3}{|l|}{ Educational background: } \\
\hline WAEC/SSCE/GCE/NECO & 48 & 6.0 \\
\hline OND/NCE/University Diploma & 112 & 13.9 \\
\hline HND & 368 & 45.8 \\
\hline BSC/BED/BA/B.ENG/B.Agric & 244 & 30.3 \\
\hline MSC/MA/MED/MBA & 32 & 4.0 \\
\hline \multicolumn{3}{|l|}{ Job status: } \\
\hline Junior staff & 428 & 53.2 \\
\hline Senior staff & 284 & 35.3 \\
\hline Top management cadre & 92 & 11.4 \\
\hline \multicolumn{3}{|l|}{ Religion: } \\
\hline Christianity & 432 & 53.7 \\
\hline Islam & 356 & 44.3 \\
\hline others & & 2.0 \\
\hline \multicolumn{3}{|l|}{ Xage $=33.38 \mathrm{yrs}$} \\
\hline \multicolumn{3}{|l|}{ SDage $=7.97$} \\
\hline \multicolumn{3}{|l|}{ Minimum age $=21 \mathrm{yrs}$} \\
\hline \multicolumn{3}{|l|}{ Maximum age $=54 \mathrm{yrs}$} \\
\hline \multicolumn{3}{|l|}{$\mathrm{X}$ work experience $=8.65$} \\
\hline \multicolumn{3}{|l|}{ SD working experience $=3.51 \mathrm{yrs}$} \\
\hline Minimum work experience $=1$ & & \\
\hline Maximum work experience $=17$ & & \\
\hline
\end{tabular}


interrelated emotional and social competencies, skills and facilitators that determine how effectively we understand and express ourselves, understand others and relate with them, and cope with daily demands (Bar-On, 2005 cited in Permall, 2011). The Bar-On model of emotional social intelligence views El in terms of the following dimensions:

\section{Social awareness and interpersonal rela- tionship:}

${ }^{*}$ To be aware of and understand how others feel.

*To identify with one's social group and cooperate with others.

${ }^{*}$ To establish mutually satisfying relationships and relate well with others.

\section{Emotional management and regulation:}

*To effectively and constructively control emotions.

*To effectively and constructively manage emotions.

\section{Change management:}

*To objectively validate one's feelings and thinking with external reality.

*To adapt and adjust one's feelings and thinking to new situations.

*To effectively solve problems of a personal and interpersonal nature.

\section{Self-motivation:}

${ }^{*}$ To be positive and look at the brighter side of life.

${ }^{*}$ To feel content with oneself, others and life in general.

In another vein, a theory explaining work engagement shall be considered. Importantly, the concept of engagement emerged in recent years as a key to effective work and learning. Engagement occurs when people undertake tasks related to their competence, learn continuously, immerse themselves and persist because of the value they attribute to the work. The concept and theory of engagement emerged in recent years as a key idea in work and learning. Essential points of the concept include:

Self-determination: one chooses to engage; assignment invalidates the process

- Direct participation is essential: observation does not suffice

Activity is assumed (it is not the goal), as is some measure of interest or pleasure

A delicate balance between sufficient competence and expertise to engage with components of challenge is important

- An open-ended situation is key; collaborative problem-solving is ideal

\section{- Routine work is not engaging}

- Persistence is characteristic

Coercion destroys engagement while communication regarding intent and purpose is fundamental (James Marcum cited in http://jameswmarcum.com/engagement-theory/)

Engagement is a process and ongoing activity, not an event. Learning and involvement are its determining characteristics (James Marcum cited in http://jameswmarcum.com/engagement-theory/). Applying the concept to information management, Davenport and Prusak (1997) utilize a sliding scale of engagement starting out with passive observation, moving to discussion, to presentation or teaching, and finally to use in practice. This mechanism serves to handle information overload, an ongoing problem, and complements the activity-engagement approach. Engagement is very similar to intrinsic motivation (IM). IM fundamentals, according to Kenneth Thomas (2009) include meaningfulness, choice, competence, and progress. But rewards also remain central in "managing" IM, as does a focus on leadership qualities to make motivation "happen." There remains an inescapable desire on the part of the "motivation industry" to assume it can be taught and managed. The assumption here is that engagement cannot be "made to happen." The initiative remains with the individual, be it worker or student. Engagement is a "bottom up," grassroots phenomenon that cannot be directed from above.

In summary: engagement occurs when an individual or group undertake tasks related to their 
Table 2: A Summary Table of t-test for independent measures showing the difference between low and high levels of overall emotional intelligence on work engagement among bank employees

\begin{tabular}{|l|l|l|l|l|l|l|}
\hline $\begin{array}{l}\text { Emotional Intelli- } \\
\text { gence }\end{array}$ & $\mathrm{N}$ & $\mathrm{SD}$ & $\mathrm{Df}$ & $\mathrm{t}$ & $\mathrm{P}$ \\
\hline $\begin{array}{l}\text { High Emotional In- } \\
\text { telligence }\end{array}$ & 398 & 65.83 & 6.39 & 802 & 3.20 & $<.05$ \\
\hline $\begin{array}{l}\text { Low Emotional In- } \\
\text { telligence }\end{array}$ & 404 & 67.57 & 8.83 & & & \\
\hline
\end{tabular}

Table 3: A Summary Table of t- test for Independent Measures Showing the difference between Low and High Levels of Emotional Intelligence Measures on Work Engagement.

\begin{tabular}{|c|c|c|c|c|c|c|c|}
\hline Emotional Intelligence Measures & $\begin{array}{l}\text { Emotional in- } \\
\text { telligence }\end{array}$ & $\mathrm{N}$ & $\mathrm{X}$ & SD & Df & $\mathrm{t}$ & $\mathrm{P}$ \\
\hline \multirow{2}{*}{$\begin{array}{l}\text { I know when to speak about my person- } \\
\text { al problems at work }\end{array}$} & High & 620 & 68.42 & 7.58 & \multirow[b]{2}{*}{804} & \multirow[b]{2}{*}{3.41} & \multirow[b]{2}{*}{$<.05$} \\
\hline & Low & 184 & 65.32 & 8.30 & & & \\
\hline \multirow{2}{*}{$\begin{array}{l}\text { When I am faced with obstacles, I re- } \\
\text { member times I faced similar obstacles } \\
\text { and overcame them }\end{array}$} & High & 691 & 67.81 & 7.48 & \multirow[b]{2}{*}{804} & \multirow[b]{2}{*}{10.66} & \multirow[b]{2}{*}{$<.01$} \\
\hline & Low & 113 & 59.91 & 5.86 & & & \\
\hline \multirow{2}{*}{$\begin{array}{l}\text { Emotions are some of the things that } \\
\text { make my life what living }\end{array}$} & High & 243 & 69.82 & 8.62 & \multirow[b]{2}{*}{804} & \multirow[b]{2}{*}{5.12} & \multirow[b]{2}{*}{$<.01$} \\
\hline & Low & 561 & 67.62 & 7.66 & & & \\
\hline \multirow{2}{*}{$\begin{array}{l}\text { I am aware of my emotions as I experi- } \\
\text { ence them }\end{array}$} & High & 436 & 63.94 & 6.63 & \multirow[b]{2}{*}{804} & \multirow[b]{2}{*}{11.97} & \multirow[b]{2}{*}{$<.01$} \\
\hline & Low & 368 & 59.99 & 5.74 & & & \\
\hline \multirow{2}{*}{$\begin{array}{l}\text { When I experience a positive emotion, I } \\
\text { know how to make it last. }\end{array}$} & High & 591 & 70.31 & 8.00 & \multirow[b]{2}{*}{804} & \multirow[b]{2}{*}{8.90} & \multirow[b]{2}{*}{$<.01$} \\
\hline & Low & 213 & 65.56 & 6.45 & & & \\
\hline \multirow[t]{2}{*}{ I am aware of the non-verbal message } & High & 534 & 68.69 & 7.67 & & & \\
\hline & Low & 270 & 62.79 & 6.34 & 804 & 10.91 & $<.01$ \\
\hline \multirow{2}{*}{$\begin{array}{l}\text { When I am in a positive mood, I am able } \\
\text { to come with new ideas. }\end{array}$} & High & 630 & 68.20 & 7.51 & \multirow[b]{2}{*}{804} & \multirow[b]{2}{*}{11.09} & \multirow[b]{2}{*}{$<.01$} \\
\hline & Low & 174 & 61.36 & 6.18 & & & \\
\hline
\end{tabular}


Solomon Ojo, IJIBM, 2017; 1:1

\begin{tabular}{|c|c|c|c|c|c|c|c|}
\hline \multirow{2}{*}{$\begin{array}{l}\text { I can easily recorgnise my emotions as I } \\
\text { experience them. }\end{array}$} & High & 126 & 65.67 & 4.92 & \multirow{2}{*}{804} & \multirow{2}{*}{-1.65} & \multirow{2}{*}{$>.05$} \\
\hline & Low & 678 & 66.91 & 8.18 & & & \\
\hline \multirow{2}{*}{$\begin{array}{l}\text { I motivate myself by imagining a good } \\
\text { outcome to task I take on. }\end{array}$} & High & 630 & 68.02 & 7.73 & \multirow{2}{*}{804} & \multirow{2}{*}{9.54} & \multirow{2}{*}{$<.01$} \\
\hline & Low & 174 & 62.03 & 5.88 & & & \\
\hline \multirow{2}{*}{$\begin{array}{l}\text { I am aware of the non-verbal messages } \\
\text { other people send }\end{array}$} & High & 602 & 67.29 & 7.77 & \multirow{2}{*}{804} & \multirow{2}{*}{3.69} & \multirow{2}{*}{$<.01$} \\
\hline & Low & 202 & 64.99 & 7.50 & & & \\
\hline \multirow{2}{*}{$\begin{array}{l}\text { When am faced with a challenge I give } \\
\text { up because I believe I will fail }\end{array}$} & High & 501 & 69.02 & 7.46 & \multirow{2}{*}{804} & \multirow{2}{*}{3.69} & \multirow{2}{*}{$<.05$} \\
\hline & Low & 303 & 62.91 & 6.70 & & & \\
\hline \multirow{2}{*}{$\begin{array}{l}\text { I help other people to feel better when } \\
\text { they are down }\end{array}$} & High & 374 & 68.07 & 8.66 & \multirow{2}{*}{804} & \multirow{2}{*}{9.41} & \multirow{2}{*}{$<.01$} \\
\hline & Low & 430 & 64.97 & 7.94 & & & \\
\hline \multirow{2}{*}{$\begin{array}{l}\text { I use good to help myself keep trying in } \\
\text { the face of obstacles. }\end{array}$} & High & 434 & 64.58 & 6.77 & \multirow{2}{*}{804} & \multirow{2}{*}{-8.84} & \multirow{2}{*}{$<.01$} \\
\hline & Low & 370 & 69.22 & 8.11 & & & \\
\hline \multirow{2}{*}{$\begin{array}{l}\text { I can tell you how people are feeling by } \\
\text { listening to the tone of their voice. }\end{array}$} & High & 541 & 66.14 & 7.91 & \multirow{2}{*}{804} & \multirow{2}{*}{-3.00} & \multirow{2}{*}{$<.05$} \\
\hline & Low & 263 & 67.88 & 7.34 & & & \\
\hline \multirow{2}{*}{$\begin{array}{l}\text { It is difficult for me to understand why } \\
\text { people feel the way they do. }\end{array}$} & High & 383 & 66.98 & 7.95 & \multirow{2}{*}{804} & \multirow{2}{*}{.96} & \multirow{2}{*}{$>.05$} \\
\hline & Low & 421 & 66.46 & 7.59 & & & \\
\hline
\end{tabular}


interests and competence, learn about them continuously, participate freely with (equal) associates, immerse themselves deeply, and continue the task with persistence and commitment because of the value they attribute to the work (James Marcum cited in http://jameswmarcum. com/engagement-theory/)

\section{METHODOLOGY}

\section{Research Design}

The study adopted survey research method. Specifically, the study utilized Ex-post factor design. The design was found appropriate because the author was not actively involved in manipulation of any variable(s) of interest. The independent variable in the study was: Emotional intelligence (high VS low). The dependent variable in the study was work engagement.

\section{Setting}

The study was carried out in banking industry. A total number of ten banks were identified and used for this study. These banks included First Bank Plc, Union Bank Plc, Zenith Bank Plc etc. These banks were selected across the five (5) states in South Western Nigeria. Majorly, the headquarters of these banks were approached in Lagos state while their branches were selected across the state capitals of the existing states within South-Western Nigeria.

\section{Participants}

A total of 804 bank employees took part in the study as participants are below in the table 1

\subsection{Instrument}

The only instrument for gathering the muchneeded primary data in the study was a structured questionnaire format. The questionnaire was made into several copies. Each copy of the questionnaire was made up of three (3) sections, namely section $A$, section $B$, section $C$. Section $A$ of the questionnaire was designed and developed by the author of the study. The section was meant to measure some personal information cum work-related information. The information collected included the following: Gender, age, marital status, educational status, job status, work experience etc.

Section B of the questionnaire was meant to measure emotional intelligence. It is a 33-item scale developed and designed by Schutte, Malaiff, Haggerty, Cooper, Golden and Dornheim (1998). The scale items measure every aspect of emotional intelligence and it has a response format likened after Likert type format. The response format ranges from "Strongly Disagree" $(\mathrm{SD})$, "Disagree" (D), "Neither Disagree nor agree" (NDA), "Agree" (A), and "Strongly Agree" (SA). In scoring the scales "SA" was scored 5 , "A" was scored 4, "NAD" was scored 3, "D" was scored 2 while "SD" was scored 1 . High scores in the scale indicated high level of emotional intelligence while low scores indicated low level of emotional intelligence. A Cronbach's alpha of 0.84 was reported for the scale in this study.

Section $C$ of the questionnaire was made to measure work Engagement. It is a 17-item scale developed and designed by Schaufeli and Bakker (2003). It is a short version of the Utrecht Work Engagement Scale (UWES)-9. The scale has a response format ranging between "Never", "Almost Never", "Rarely", "Sometimes", "Often", "Very Often" and "Always". In scoring the scale, "Never" was scored 0; "Almost Never" was scored 1; "Rarely" was scored 2; "Sometimes" was scored 3; "Often" was scored 4; "Very Often" was scored 5; while "Always" was scored 6. The scale items include: "At my work, I feel bursting with energy" "I find the work that I do full of meaning and purpose"; Time flies when I am working; "At my job; "I feel strong and vigorous";"I am enthusiastic about my job"; "when I am working, I forget everything else around me"; etc. Based on this study, a Cronbach's alpha of 0.83 was reported for the scale in this particular study.

\section{Procedure}

The study was directed at selected banks in Southwestern Nigeria. A total of ten (10) banks that have stood the test of time were approached for the study. The headquarters were first of all approached to gather first-hand information before their branches scattered across the existing five (5) states in South-Western Nigeria were equally approached. These states were Oyo, Osun,Ondo,Ekiti and Lagos states.

Out of the distributed 1000 copies of questionnaire, the author with the assistance of twenty (20) recruited research assistants and five re- 
search supervisor, was able to retrieve 823 copies in which 19 copies were not fit for data coding and analysis and so, only 804 copies were found fit and hence coded manually and later encoded into the computer for onward data analysis. The Author, the recruited research supervisors and research assistants instructed the participants not to include their names on the copies of the questionnaire and even some other personal identifying information. However, the participants were assured of utmost confidentiality of their responses.

The data collection activity lasted for six (6) months.

\section{Statistical Analysis}

The study utilized both the Descriptive and Inferential Statistics for data analysis. The descriptive statistics was meant to provide some summary information on some data, particularly the personal and work related information associated with the participants of the study which included frequency, percentage, mean etc. The inferential statistics was used to test the stated hypotheses. Specifically, the study utilized only the statistical test of t-test for independent measures.

\section{RESULTS}

The results of the study are presented in this chapter. In all, two (2) hypotheses were stated and tested in the study. The hypotheses were tested with inferential statistics of t-test for independent measures. The results are shown below.

\section{Hypothesis One}

This stated that bank employees who are high on emotional intelligence would report more work engagement than bank employees who are low on emotional intelligence. The hypothesis was tested by t-test for independent measures. The result is show in table 2 below.

The result in table 2 above revealed that bank employees who were high on emotional intelligence reported more work engagement than bank employees who are low on emotional intelligence [t $(802)=3.20, P<.05]$. Clearly, the result showed that bank employees who were high on emotional intelligence had a higher mean score $(X=65.83)$ on work engagement than bank em- ployees who were low on emotional intelligence $(X=67.57)$

Therefore, it is stated that the hypothesis one was supported by the result of the study in the stated direction.

\section{HYPOTHESIS TWO}

This stated that bank employees who are high on some measures of emotional intelligence would report more work engagement than bank employees who are low on some measures of emotional intelligence.

The result in table 3 above revealed the specific influence of each of the selected items measuring emotional intelligence on work engagement among bank employees. It was vividly revealed that bank employees who were high on emotional intelligence measure of "I know when to speak about my personal problems at work" reported more engagement than bank employees who were low on emotional intelligence measure $\{t(802)=3.41, p<.05\}$. The difference between low and high measure emotional intelligence on work engagement was wide enough, in which bank employees who were low on the measure $(X=68.42)$ had a higher mean score on work engagement than bank employees who were low on the measure $(X=65.32)$.

The result in table 3 revealed that bank employees who were high on emotional intelligence measure of "When I am faced with obstacles, I remember times I faced similar obstacles and overcame them" reported more work engagement than bank employees who were low on emotional intelligence measure $\{\mathrm{t}(802)=10.66$, $p<.01\}$. In view of this, it was clearly revealed that bank employees with high score on the emotional intelligence measure $(X=67.81)$ had a higher mean score on work engagement than bank employees with low score on the emotional intelligence measure $(X=59.91)$.

Further, the result portrayed again that bank employees who were high on emotional intelligence measure of "Emotions are some of the things that make my life worth living" reported more work engagement than bank employees who were low on emotional intelligence measure $\{t(802)=5.12, p<.05\}$. In support of this, bank employees with higher level on the emotional 
intelligence $(X=69.82)$ had a higher mean score on work engagement than bank employees with lower level on the emotional intelligence measure $(X=67.62)$.

In a similar vein, the result revealed that bank employees who were high on the emotional intelligence measure of " I am aware of mu emotions as I experience them" reported more work engagement than bank employees who were low on the emotional intelligence measure $\{(802)=11.97, p<.01\}$. In this vein, bank employees with higher level of the emotional intelligence measure $(X=63.94)$ had a higher mean score on work engagement than bank employees with lower level of the emotional intelligence measure $(X=59.99)$.

Further, the results revealed that bank employees who were high on the emotional intelligence measure of "When I experience a positive emotion, I know how make it last" reported more work engagement than bank employees who were low on the emotional intelligence measure [t $(802)=8.90, p<.01]$. Along this results, the bank employees who were high on the emotional intelligence measure $(X=70.31)$, had a higher mean score on work engagement than bank employees who were low on emotional intelligence measure $(X=65.56)$.

Similarly, the results showed that bank employees who were high on the emotional intelligence of "I am aware of the non-verbal messages I send to others", were found to report more work engagement than bank employees who were low on the emotional intelligence $[\mathrm{t}(804)=10.91$, $p<.01]$. Also, it was revealed clearly that bank employees who were high on the emotional intelligence of "When I am in a positive mood, I am able to come up with new ideas" were found to report more work engagement than bank employees who were low on the emotional intelligence measure [t $(804)=11.09, p<.05]$. Howev$\mathrm{er}$, the result revealed that bank employees who were high and low on the emotional intelligence measure of "I easily recognise my emotions as I experience them" were not significantly different on work engagement.

Further, the result revealed that bank employees who were high on the emotional intelligence measure of "I motivate myself by imagining a good outcome to tasks I take on" reported more work engagement than work bank employees who were low on the emotional intelligence [ $t$ $(802)=9.54, p<.05]$. The result showed that bank employees who were high on the emotional intelligence measure of "I am aware of the non-verbal messages other people send" reported more work engagement than bank employees who were low on the emotional intelligence measure $[t(802)=3.69, p<.05]$. Also, the results portrayed that bank employees who were low on the emotional intelligence measure of "When I am faced with a challenge, I give up because I believe I will fail" were found to report more work engagement than bank employees who were low on the emotional intelligence measure $[t(804)=$ $11.71, p<.05]$.

However, the result in table 3 above showed that bank employees who were low on the emotional intelligence measure of "I help other people feel better when they are down" were found to report more work engagement than bank employees who were high on the emotional intelligence measure $[t(804)=-9.41, p<.01]$. Similarly, the result showed that bank employees who were low on the emotional intelligence measure of "I use good mood to help myself keep trying in the face of obstacles" were found to report more work engagement than bank employees who were high on the emotional intelligence measure [t $(802)=8.84, p<.01]$. In a similar vein, the result showed that bank employees who were high on the emotional intelligence measure of "I can tell how people are feeling by listening to the tone of their voice" reported more work engagement than bank employees who were low on the emotional intelligence measure $[\mathrm{t}(804)=-3.00$, $p<.05]$.

Finally, the result showed that bank employees who were high and low on the emotional intelligence measure of "It is difficult for me to understand why people feel the way they do" were not significantly different on work engagement [ $t$ $(804)=.96, p>.05]$.

In this vein therefore, the hypothesis two was found to be supported partially by the results of the study.

\section{DISCUSSION}

This study investigated the influence of emotional intelligence on work engagement among 
bank employees, in South-Western Nigeria. The study was purely an empirical study, in which a total of ten (10) different banks were selected and used for the study.

Importantly, the place of work engagement to organizational development and survival cannot be under-estimated. Therefore, the contributions of emotional intelligence to work engagement cannot also be under-estimated. In view of this therefore, this study has contributed immensely in investigating the role of emotional intelligence on work engagement. The study stated and tested two (2) hypotheses.

In line with this, the hypothesis one which stated that bank employees who are high on emotional intelligence would report more work engagement than bank employees who are low on emotional intelligence was fully supported by the result of the study. It was clearly revealed, indeed, that bank employees who were high on emotional intelligence reported more work engagement than bank employees who were low on emotional intelligence. This result has pointed on that emotional intelligence plays a great deal of role in bringing about work engagement among employees in work organizations generally and in the banking industry specifically. Also, nearly all of the selected specific measures of emotionally intelligence were found to influence bank employees' work engagement significantly.

\section{CONCLUSION}

In view of what has been stated and discussed above, it is therefore concluded that emotional intelligence (in overall) significant influence on work engagement of employees' in the banking industry. Similarly, over $86 \%$ of the selected specific of emotional intelligence showed significant influence on bank employees' work engagement.

\section{References}

Bar-On, R. (1997). Bar-On Emotional Quotient Inventory (EQ-i): Technical Manuel. Toronto, Canada. Multi Health Systems.

Bar-On, R. (2003). How important is it to educate people to be emotionally and socially intelligent, and can it be done? Perspectives in Education. 21(4). 3-15.

Bar-On, R. (2005). The impact of emotional intelligence on subjective well-being. Perspectives in Education, 23(2). 41-62.
Bar- On, R. (2010). Emotional Intelligence: an integral part of positive psychology.SA Journal of Psychology. 401. 54-62.

Goleman, D. (2001). An El-based theory of performance. In C.Cherniss\& D.

Goleman (Eds.). The emotionally intelligent workplace. San Francisco: Jossey Bass. 27-44.

Kahn, W.A. (1990). Psychological conditions of personal engagement and disengagement at work. Academy of Management Journal. 33. 692-724.

Permall, C.L. (2011). Emotional Intelligence and Work Engagement of Leaders in a Financial services Organisation Undergoing Change. Being aMini-thesis submitted in partial fulfillment of the requirements for the degree of Magister Commercii in the Department of Industrial Psychology, Faculty of Economic and Management Sciences, at the University of the Western Cape. Supervisor: Karl Heslop

Schaufeli,W. B., \& Bakker, A. B. (2003). The Utrecht Work Engagement Scale (UWES): Test manual. Utrecht, The Netherlands: Department of Social and Organizational Psychology.

Schaufeli, W. B., Salanova, M., Gonzalez Roma, V., \& Bakker, A. B. (2002b). The measurement of engagement and burnout: A two sample confirmatory factor analytic approach. Journal of Happiness Studies, 3, 71-92.

Mayer, J. D., Caruso, D. R., \& Salovey, P. (2000). Selecting ameasure of emotional intelligence:

The case for ability scales. In R. Bar-On \& J. D. A. Parker (Eds.), The handbook of

emotional intelligence: Theory, development, assessment, and application at home,

school, and in the workplace (pp. 320-342). San Francisco, CA: Jossey-Bass.

Mayer, J. D., Salovey, P., \& Caruso, D. R. (2000). Models of emotional intelligence. In R. J.

Sternberg (Eds.), The handbook of intelligence (pp. 396-420). New York, NY: Cambridge University Press.

Mayer, J. D., Salovey, P., Caruso, D. R., \& Sitarenios, G. (2003). Measuring emotional

intelligence with the MSCEIT v2.0. Emotion, 3(1), 97-105.

Mayer, J.D. (2007). A new field guide to emotional intelligence. In J. Ciarrochi, J. Forgas \& J.

Mayer (Eds.), Handbook of intelligence. Cambridge, U.K.: Cambridge University Press.

McGregor, D. (1957, November). The human side of enterprise, Management Review, 46, 22-28, 8892.

Morgan, G. (2006). Images of organization. Thousand Oaks, CA: Sage Publications, Inc.

Schaufeli, W., \& Bakker, A. (2010).Defining and measuring work engagement: Bringing clarity to the concept. In A. B. Bakker \& M. P. Leiter (Eds.), Work engagement: A handbook of essential theory and research(pp. 10-24). New York, NY: Psychol- 
ogy Press.

Locke, E. A. (1976). The nature and causes of job satisfaction. In M.D. Dunnette (Ed.), Handbook of industrial and organizational psychology (pp. 12111254). Chicago, IL: Rand McNally.

Locke, E. A. (2005). Why emotional intelligence is an invalid concept. Journal of Organizational Behavior, 26, 425-432.

Lodahl, T. M., \& Kejner, M. (1965). The definition and measurement of job involvement.Journal of Applied Psychology, 49, 24-33.

Lopes, P. N., Grewal, D., Kadis, J., Gall, M., \& Salovey, P. (2006). Evidence that emotional

intelligence is related to job performance and affect and attitudes at work. Psicothema, 18, 132-138.

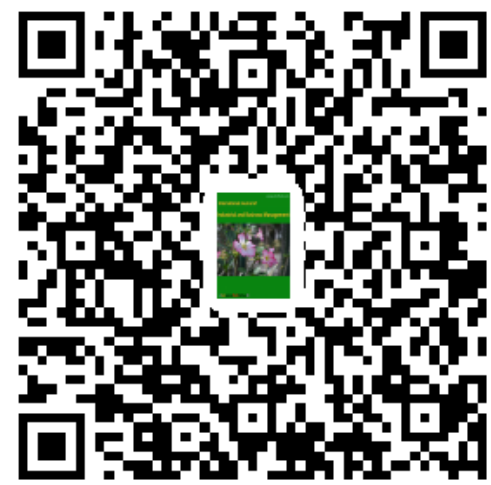

